\title{
Wintry Lodge on a White Mountain
}

Wine and dine and after the hunt we call the dogs together around the footstool and all manner of sot-scape, have a draught, inhalations most robust. Our guns are clean as whistles, our whistles are slightly wet. We've thanked our commodious hostess. The dogs take taboo sleep. Their fog-headed, gum-rheumy blear-eyes clammed over as if they'd slept for days or so already. We laughed through the black and pink proceedings. The telephone prattled in its cradle severally. The typewriter was manhandled with many absent-minded and suspensive smacks and did come full-swing, full-throttle homeward as a well-heeled moth of rusty colors and chalky complexion alights on the stag's nostrils only to follow its destiny and path pre-ordained to find cashmere near (and venison leather). No food is truly blue, except our cheese and the whole berry family, plump as thumbs. And those were some damn fine fruit platters, greasy as the sun shines high. Are you still there whiling away among the hunters newly returned with flasks and pelts of hare past the gleaners and reapers, toward the inn which isn't open? The moon empties out gladsome, the village is well and the hut's not far from here either. A soft group of apes is a shrewdness. Jaw muscles bristle over gristle. Gentler specimens otherwise asleep at their plates, ties wiped with sauces. Poor, tired dogs, all. 